\title{
QSAR Study on Novel CCR5 Receptor Antagonists: An Insight into the Structural Requirement for the HIV Co Receptor Antagonist Activity
}

\author{
Nigus Dessalew
}

Department of Pharmaceutical Chemistry, School of Pharmacy, Addis Ababa University, P.O. Box 1176, Addis Ababa, Ethiopia

E-mail: dnigus@phar.aau.edu.et

Sci Pharm. 2008; 76: 605-620

doi:10.3797/scipharm.0807-20

Published: November $1^{\text {st }} 2008$

Accepted: $\quad$ October $28^{\text {th }} 2008$

Received: July $28^{\text {th }} 2008$

This article is available from: http://dx.doi.org/10.3797/scipharm.0807-20

(C) Dessalew; licensee Österreichische Apotheker-Verlagsgesellschaft m. b. H., Vienna, Austria.

This is an Open Access article distributed under the terms of the Creative Commons Attribution License (http://creativecommons.org/licenses/by/3.0/), which permits unrestricted use, distribution, and reproduction in any medium, provided the original work is properly cited.

\begin{abstract}
Chemokines receptors have emerged as important drug targets for development of agents against the HIVIAIDS pandemic. With the purpose of designing new chemical entities with enhanced antagonistic potencies against the CCR5 chemokine receptor, the QSAR study carried out on 70 novel phenoxybenzyl derivatives as antagonists of CCR5 HIV co receptor is presented. The developed model was validated by standard QSAR parameters and through a detailed structural analysis on how it reproduces the quantitative differences observed in the experimentally known activity data. The model showed a good correlative and predictive ability having a cross validated correlation co-efficient $\left(r_{\text {cv }}^{2}\right)$ of 0.708 and a conventional correlation coefficient $\left(r^{2}\right)$ was found to be 0.805 . The study revealed that the CCR5 antagonistic activity exhibited by the series is largely explained by steric factors of substituents emphasizing the role of size and shape of the inhibitors in making effective antagonist-CCR5 binding chemistry. A detailed investigation was made on the structural basis for the antiretroviral activity and the insights gleaned from the study could be usefully employed to design antagonists with a much more enhanced potency and selectivity.
\end{abstract}

\section{Keywords}

QSAR • HIVIAIDS • CCR5 • Phenoxybenzyls • TSAR 


\section{Introduction}

Despite efforts to prevent the spread of human immunodeficiency virus (HIV), the worldwide population of HIV infected patients keeps alarmingly on the rise. The development of combination antiretroviral therapy comprised of reverse transcriptase inhibitors and protease inhibitors has provided a useful means of suppressing viral load in HIV infected subjects and has resulted in dramatic reductions in HIV associated morbidity and mortality [1]. However, none of the current therapies are curative [2] and HIV replicates rapidly when treatment ceases [3]. The complexity of the dosing regimens and the toxicity of the current antiretroviral therapy make it difficult to maintain patient compliance [4]. In addition, resistance to the currently available drugs is increasing [5]. Therefore, there remains a need to identify new classes of agents with improved efficacy and less toxicity.

The process of HIV entry into host cells is one of the attractive targets for inhibition of HIV replication [6]. Recent successful studies with enfuvirtide, a peptide inhibitor of gp41mediated HIV entry, have confirmed this process as a clinically relevant target [7]. It has been reported that HIV strains that cause the initial infection predominantly utilize chemokine receptor 5 (CCR5) as a co receptor [8]. CCR5 is a member of the seventransmembrane G-protein-coupled receptor superfamily [9]. The natural ligands for CCR5 are the chemokines, which have been reported to inhibit HIV infection in vitro [10]. Individuals homozygous for a defect in CCR5 expression have been identified as being highly resistant to HIV infection, while this defect does not cause a significant health problem [11-13]. In addition, infected individuals heterozygous for the defective gene appear to exhibit delayed disease progression [14]. Given the importance of HIV coreceptors in viral entry and replicative life cycle, chemokine receptors have become one of the most promising targets for antiretroviral drug discovery [15-21].

TSAR is an integrated analysis package for interactive investigation of quantitative structure-activity relationships [22-24]. It provides functions required to carry out any QSAR investigation whether in pharmaceutical, agrochemical, toxicological, or any other area of application. In common with all QSAR a method [25-28], it is based on a numerical description of molecular structure and employs statistics to obtain a correlation. Molecular structures are represented with a variety of 2D and 3D descriptors, the activity-descriptor relationship is computed by different standard statistical tools such as multiple regression, partial least square regression and neural network analysis, and the output is displayed in the form of a model highlighting substituent points that are strongly correlated with the pharmacotoxicological properties under investigation. The TSAR methodology assumes that a suitable sampling of these structural descriptors provides all the information needed for understanding their biological properties. TSAR has been employed to investigate the structural basis for the antiproliferative activity of aminophenylbenzamides and acrylamides [29]. Recently, researchers have applied TSAR to study the structural requirement for the antidepressant activity activity by theinpyrimidinone derivatives and found that that the 5-HT autoreceptor antagonistic activity exhibited by the series is largely explained by steric bulkiness of substituents [30]. Lohray et al. [31] have applied TSAR to analyse the structural requirement for the antibacterial properties of phenyloxazolidinone derivatives while Tronchet et al have applied TSAR to study the interaction of 6phenylthiothymine derivatives with the HIV reverse transcriptase [32] These all may attest 
the usefulness of such a methodology in understanding the structural requirements for the pharmacological properties of a given series.

The intense research on small molecule inhibitors of chemokine receptors has produced a diverse class of chemical scaffolds. Figure 1 shows some CCR5 antagonists. Although diverse in structure and large in number, most of them are beset with the problem of nonselectivity and weak binding affinity. TSAR, in common with other QSAR tools, is generally employed to enhance and optimize the binding affinity using a series of compounds acting on the same target with the same mechanism of actions. As a quantitative pharmacophore mapping tool, such a methodology is valuable in pinpointing the structural requirements for the observed pharmacotoxicological properties by the series. Such insights are an aid to design a new entity having an acceptable level of potency and selectivity. In this paper, we report the QSAR study carried out on 70 novel CCR5 antagonists in the anticipation of getting a model that would account for the quantitative differences in bioactivity seen in this series and to capitalize upon the insights to design ligands with pronounced inhibitory potency and selectivity.

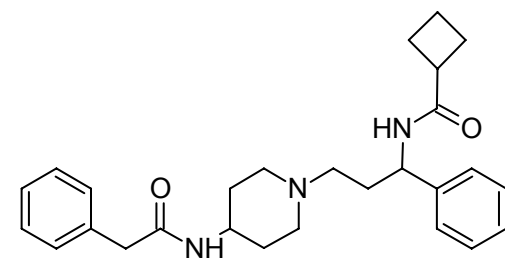

EP 1013276

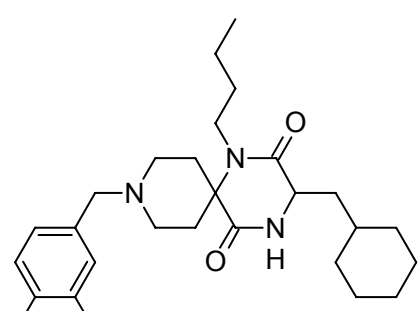

E913<smiles>CN1CC(C(=O)N(CCCN2CCC(Cc3ccccc3)CC2)c2ccccc2)CC1=O</smiles>

W00066551

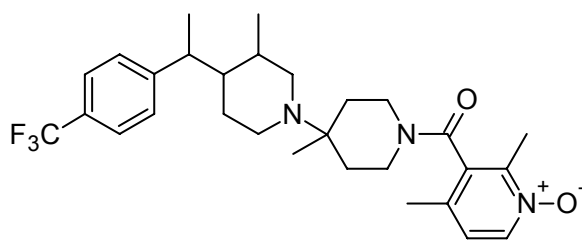

Sch-350634

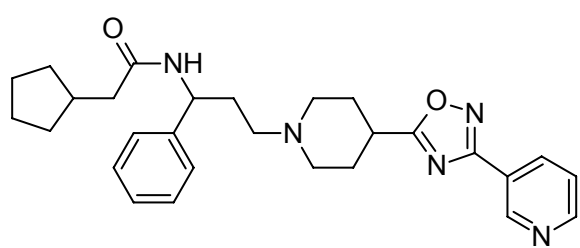

WO200039125

Fig. 1: Examples of CCR5 antagonists

\section{Computational Details}

\section{Dataset for Analysis}

The in vitro biological activity data reported as $\mathrm{IC}_{50}$ for inhibition of CCR5 co-receptors by a series of phenoxybenzyl derivatives $[33,34]$ was used for the current study. As biological activities are generally skewed, the reported $I_{50}$ values were converted into the corresponding $\mathrm{plC}_{50}$ using the following formula:

$$
\mathrm{plC}_{50}=-\log \mathrm{C}_{50}
$$




\section{Molecular Modeling}

The structures of the phenoxybenzyl derivatives selected for the present QSAR study are shown in Table 2. The structures were sketched using ChemDraw ultra 8.0 and were exported to TSAR 3.3 software (www.accelrys.com). Three-dimensional structures of all the molecules were generated. Partial charges were derived using Charge-2 CORINA 3D package in TSAR 3.3 and their geometries were optimized using Cosmic module of TSAR. The calculations were terminated when the energy difference or the energy gradient were smaller than $1 \mathrm{e}-005$ and $1 \mathrm{e}-010 \mathrm{kcal} / \mathrm{mol}$ respectively.

Molecular descriptors were calculated with TSAR 3.3. The descriptors were obtained for the substituents which vary from one molecule to another at a common point on the generic structure. TSAR affords calculation of the following descriptors: molecular surface area and volume, moments of inertia, ellipsoidal volume, verloop parameters, dipole moments, lipole moments, molecular mass, Wiener index, molecular connectivity indices, molecular shape indices, electrotopological state indices, logP, number of defined atoms (carbon, nitrogen, etc.), rings (aromatic and aliphatic), and groups (methyl, hydroxyl, etc.). Vamp which is a semiempirical molecular orbital package in TSAR 3.3 was used to calculate the electrostatic properties like total energy, electronic energy, nuclear repulsion energy, accessible surface area, atomic charge, mean polarizability, heat of formation, total dipole, polarizability, and dipole components. Structure optimization was performed in vacuo using default parameters with the AM1 Hamiltonian. Pairwise correlation analysis of the calculated descriptors was performed. The model was obtained using descriptors that are strongly correlated with the HIV entry blocking activity.

\section{Statistical Analysis}

The relationship between the structural parameters (TSAR descriptors) and the biological activities has been quantified by the multiple linear regressions implemented in TSAR 3.3. Values for F-to-enter and F-to-leave were set to 4 . The cross-validation analysis was performed using leave-one-out (LOO) method where one compound is removed from the dataset and its activity is predicted using the model derived from the rest of the dataset. The cross-validated $r^{2}$ and conventional $r^{2}$ that resulted in lowest error of prediction was taken. Unless otherwise stated, the default values for the other TSAR QSAR parameters were used. The predictive capabilities of the QSAR model were determined using test set compounds that were excluded during model development. The structure generation, optimization, charge derivation, structural descriptor calculations and all other steps of the test sets were done in the same way with that of the training set compounds as described above, and their activities were predicted using the model produced by the training set.

\section{Results and Discussion}

The QSAR study was carried out using novel phenoxybenzyl derivatives which are reported as novel HIV entry inhibitors. Molecules, which lack biological inhibitory activity in numerical form, were removed from the analysis. Following this, 70 molecules were left for the present study. During the processes of model development and validation, two molecules were found not to fit to either the training set or test sets. Outliers generally exist when they posses a unique scaffold and hence act on a different receptor or when they act on a different binding site of the same receptor or because of the limitations on the quality of the biological data. But the structures of these molecules are not that unique to claim 
that they bind differently. These too were removed and the remaining dataset was partitioned into a training set of 43 and a test set of 25 compounds at random with bias given to both chemical and biological diversity in both the training and test set molecules. Despite the ambiguity of drug-receptor interaction in general, a statistically significant model were obtained from the TSAR study.

The TSAR multiple regression analysis is summarized in Table 1. The cross-validated correlation coefficient defines the goodness of prediction whereas the non-cross-validated conventional correlation coefficient indicates goodness of fit of a QSAR model. The F-test value stands for the degree of statistical confidence. As it is evident from the body of table, a cross-validated correlation coefficient of 0.708 was obtained using leave-one-out crossvalidation procedure. This indicates a very good internal predictive capability of the developed model. The model also exhibited a non-cross validated correlation coefficient of 0.805 . The external predictive capability of a QSAR model is generally checked using test sets. All procedures including geometry optimization, charge computation, calculation of structural descriptors of the 25 test set molecules were done in a manner analogous to the training set molecules. The prediction of the test set molecules presented in Table 2 shows a satisfactory prediction indicating its usefulness in predicting activities of external molecules. Yet another way to further evaluate the usefulness of the developed model is to test for statistical stability. To this end, standard error of estimate and predictive residual sum of squares may be employed. The low values of standard error of estimate (0.299) and that of PRESS for training set (3.497) and test sets (7.897) further add to the statistical significance of the developed models. Table 3 shows the descriptors included in the final QSAR model and their statistical significance.

Tab. 1. Statistical parameters obtained for the TSAR model

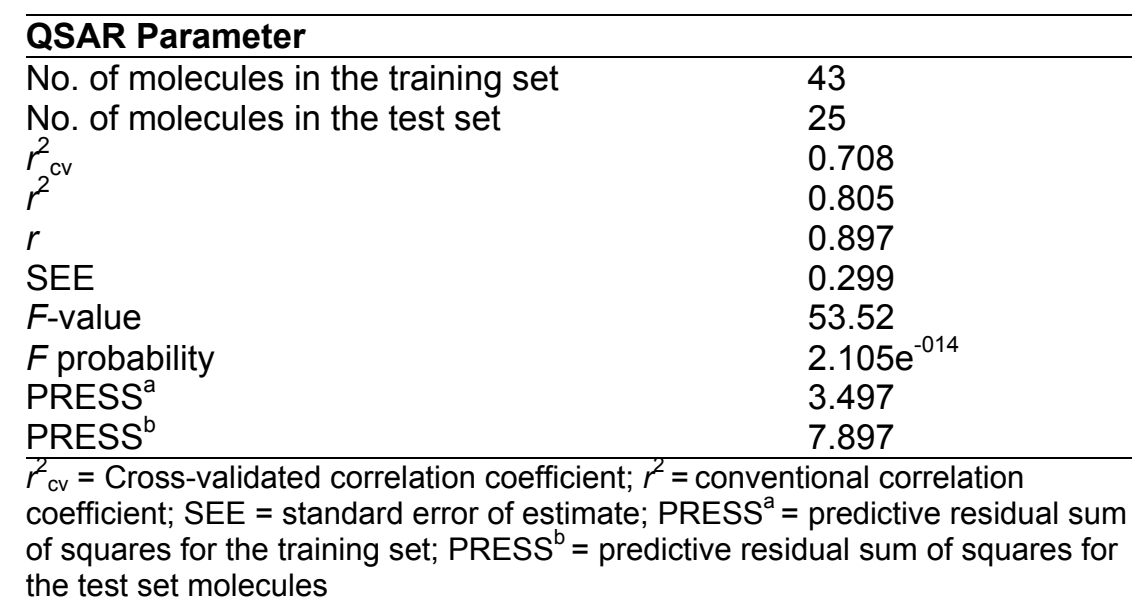

The structures of the inhibitors chosen and the actual and predicted activity are displayed in Table 2 while that of test sets is presented in Table 3 . Figure 2 shows plots of actual versus predicted $\mathrm{plC}_{50}$ values for the training set molecules. The histograms of residuals of the test set molecules is presented in Figure 3. 


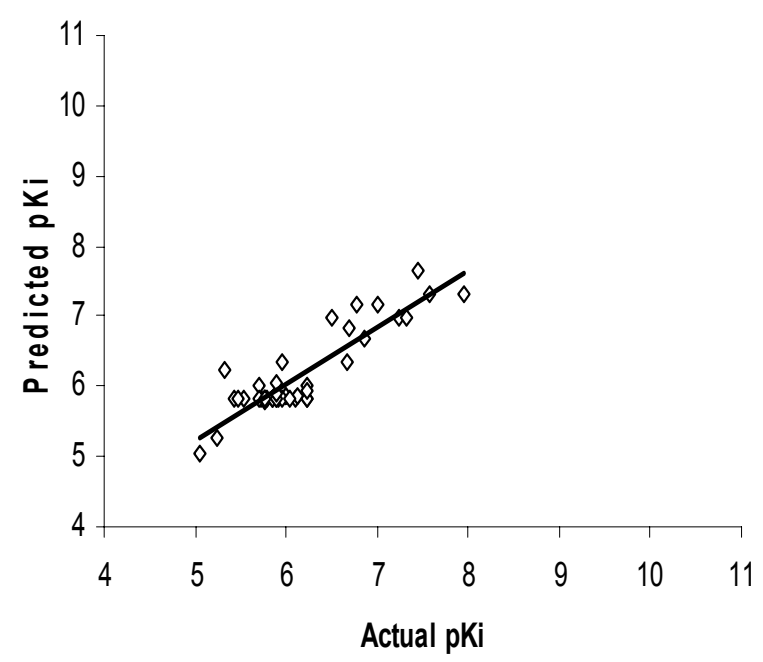

Fig. 2. Plots of actual versus predicted

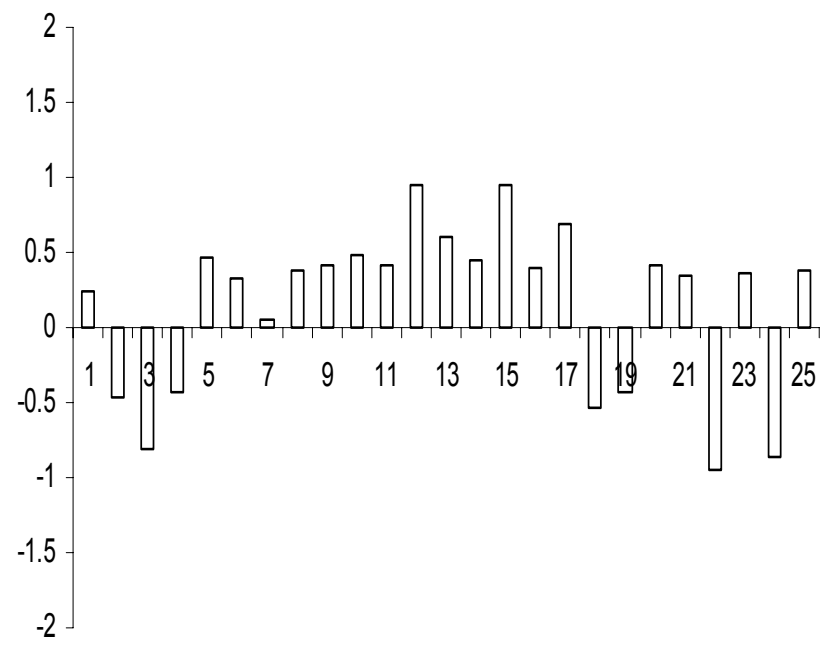

Fig. 3. Histograms of residuals of the test set molecules $\mathrm{pK}_{\mathrm{i}}$ values for Training set molecules 
<smiles>[R]c1cc([R])c(COc2cc([R])c([R])cc2[R])cc1[R]</smiles>

Tab. 2. Structures and the corresponding actual and predicted activities of the training sets.

\begin{tabular}{|c|c|c|c|c|c|c|c|c|c|c|c|}
\hline \multirow{2}{*}{ No. } & \multicolumn{3}{|c|}{ Antagonist Activity } & \multicolumn{3}{|c|}{ Substitutions } & \multirow[b]{2}{*}{$\mathbf{R}^{5}$} & \multirow[b]{2}{*}{$\mathbf{R}^{6}$} & \multicolumn{3}{|c|}{ Structural Descriptors } \\
\hline & Act. pr & Pred. & Resid. R & $\mathbf{R}^{2}$ & $\mathbf{R}^{3}$ & $\mathbf{R}^{4}$ & & & $\begin{array}{l}\text { Verloop } \\
\text { L }\end{array}$ & $\begin{array}{l}\text { Verloop } \\
\text { B1 }\end{array}$ & $\begin{array}{l}\text { Weiner } \\
\text { Index }\end{array}$ \\
\hline$\overline{1}$ & 5.244 & 5.278 & -0.034 & $\mathrm{Br}$ & $\mathrm{H}$ & $\mathrm{H}$ & $\mathrm{H}$ & $\mathrm{NO}_{2}$ & 3.54 & 1.65 & 32 \\
\hline 2 & 6.495 & 6.996 & -0.501 & $\mathrm{Br}$ & $\mathrm{H}$ & $\mathrm{H}$ & $\mathrm{Cl}$ & $\mathrm{H}$ & 2.09 & 1.65 & 1028 \\
\hline 3 & 7.244 & 6.995 & 0.249 & $\mathrm{Br}$ & $\mathrm{H}$ & $\mathrm{H}$ & $\mathrm{Cl}$ & $\mathrm{H}$ & 2.09041 & 1.65 & 1028 \\
\hline 4 & 6.770 & 7.161 & -0.391 & $\mathrm{Br}$ & $\mathrm{H}$ & $\mathrm{H}$ & $\mathrm{Cl}$ & $\mathrm{H}$ & 2.08917 & 1.65 & 1170 \\
\hline 5 & 7.000 & 7.161 & -0.161 & $\mathrm{Br}$ & $\mathrm{H}$ & $\mathrm{H}$ & $\mathrm{Cl}$ & $\mathrm{H}$ & 2.08996 & 1.65 & 1170 \\
\hline 6 & 7.328 & 6.996 & 0.332 & $\mathrm{Br}$ & $\mathrm{H}$ & $\mathrm{H}$ & $\mathrm{Cl}$ & $\mathrm{H}$ & 2.08957 & 1.65 & 1028 \\
\hline 7 & 7.959 & 7.313 & 0.646 & $\mathrm{Br}$ & $\mathrm{H}$ & $\mathrm{H}$ & $\mathrm{Cl}$ & $\mathrm{H}$ & 2.088 & 1.65 & 1300 \\
\hline 8 & 7.456 & 7.648 & -0.192 & $\mathrm{Br}$ & $\mathrm{H}$ & $\mathrm{H}$ & $\mathrm{Cl}$ & $\mathrm{H}$ & 2.090 & 1.65 & 1588 \\
\hline 9 & 7.569 & 7.313 & 0.256 & $\mathrm{Br}$ & $\mathrm{H}$ & $\mathrm{H}$ & $\mathrm{Cl}$ & $\mathrm{H}$ & 2.089 & 1.65 & 1300 \\
\hline 10 & 5.886 & 5.834 & 0.052 & $\mathrm{Br}$ & $\mathrm{H}$ & $\mathrm{H}$ & $\mathrm{CO}_{2} \mathrm{Me}$ & $\mathrm{H}$ & 2.094 & 1.65 & 32 \\
\hline
\end{tabular}


Tab. 2. (Cont.)

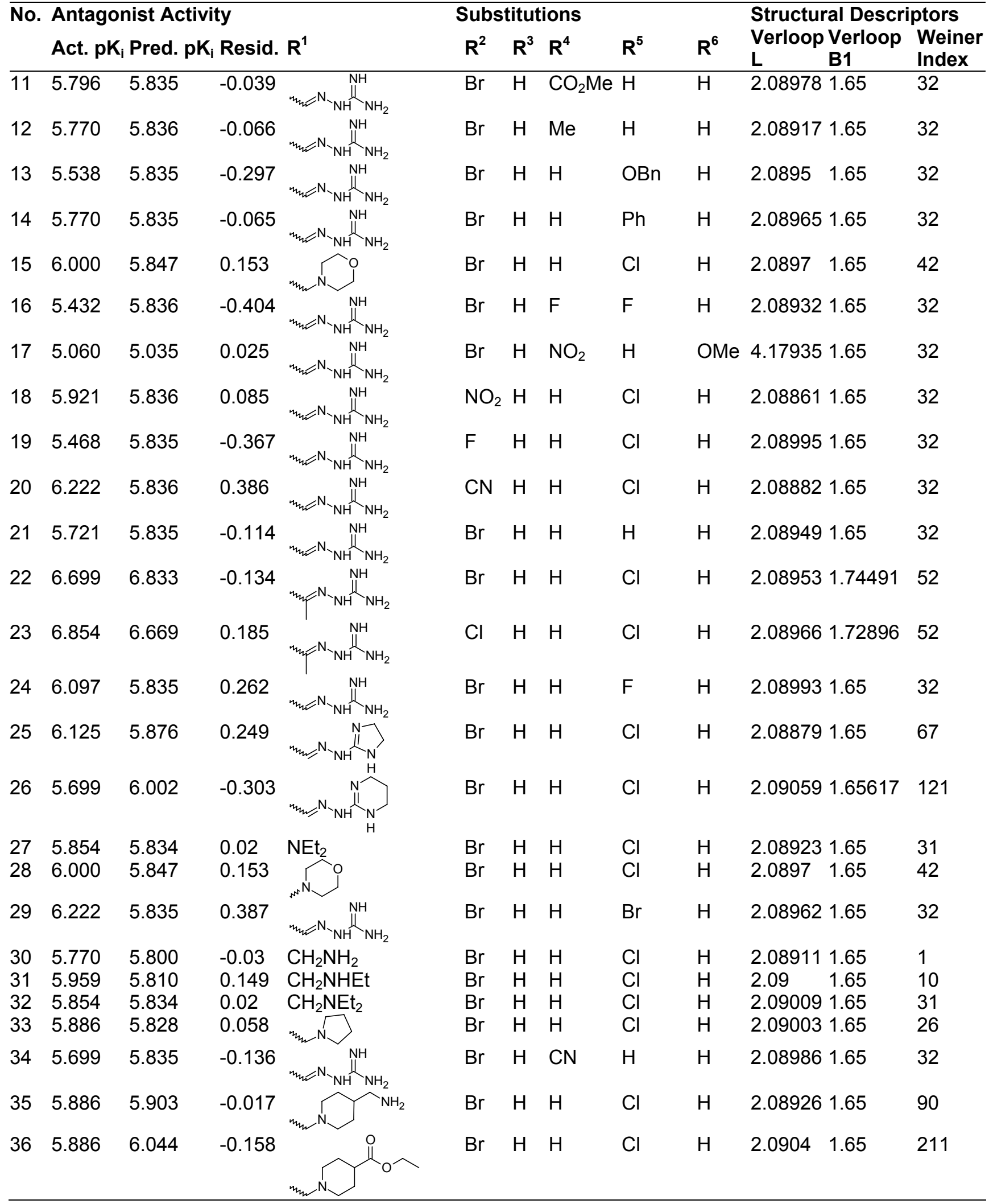


Tab. 2. (Cont.)

\begin{tabular}{|c|c|c|c|c|c|c|c|c|c|c|c|c|}
\hline \multicolumn{5}{|c|}{ No. Antagonist Activity } & \multicolumn{5}{|c|}{ Substitutions } & \multicolumn{3}{|c|}{ Structural Descriptors } \\
\hline & Act. pK & Pred. $p$ & Resid. & & $\mathbf{R}^{2}$ & $\mathbf{R}^{3}$ & $\mathbf{R}^{4}$ & $\mathbf{R}^{5}$ & $R^{6}$ & $\begin{array}{l}\text { Verlook } \\
\text { L }\end{array}$ & $\begin{array}{l}\text { p Verloop } \\
\text { B1 }\end{array}$ & $\begin{array}{l}\text { Weiner } \\
\text { Index }\end{array}$ \\
\hline$\overline{37}$ & 6.046 & 5.836 & 0.210 & & $\mathrm{Br}$ & $\mathrm{H}$ & $\mathrm{H}$ & $\mathrm{NO}_{2}$ & $\mathrm{H}$ & 2.08875 & 51.65 & 32 \\
\hline 38 & 5.770 & 5.835 & -0.065 & & $\mathrm{Br}$ & $\mathrm{H}$ & $\mathrm{NO}_{2}$ & $\mathrm{H}$ & $\mathrm{H}$ & 2.09033 & 31.65 & 32 \\
\hline 39 & 6.237 & 6.011 & 0.226 & & $\mathrm{Br}$ & $\mathrm{H}$ & $\mathrm{H}$ & $\mathrm{Cl}$ & $\mathrm{H}$ & 2.08974 & 41.65 & 183 \\
\hline 40 & 5.319 & 6.220 & -0.901 & & $\mathrm{Br}$ & $\mathrm{H}$ & $\mathrm{H}$ & $\mathrm{Cl}$ & $\mathrm{H}$ & 2.09010 & 91.65 & 362 \\
\hline 41 & 6.237 & 5.932 & 0.305 & & $\mathrm{Br}$ & $\mathrm{H}$ & $\mathrm{H}$ & $\mathrm{Cl}$ & $\mathrm{H}$ & 2.08934 & 41.65 & 115 \\
\hline 42 & 5.959 & 6.334 & -0.375 & & $\mathrm{Br}$ & $\mathrm{H}$ & $\mathrm{H}$ & $\mathrm{Cl}$ & $\mathrm{H}$ & 2.08942 & 21.65 & 460 \\
\hline 43 & 6.678 & 6.334 & 0.344 & & $\mathrm{Br}$ & $\mathrm{H}$ & $\mathrm{H}$ & $\mathrm{Cl}$ & $\mathrm{H}$ & 2.08917 & 71.65 & 460 \\
\hline 44 & 6.076 & 5.835 & 0.241 & & $\mathrm{Br}$ & $\mathrm{H}$ & $\mathrm{Cl}$ & $\mathrm{H}$ & $\mathrm{H}$ & 2.09 & 1.65 & 32 \\
\hline 45 & 5.824 & 6.295 & -0.471 & & $3 r$ & $\mathrm{H}$ & $\mathrm{H}$ & $\mathrm{Cl}$ & $\mathrm{H}$ & 2.09 & 1.65 & 942 \\
\hline 46 & 6.347 & 7.161 & -0.814 & & $\mathrm{Br}$ & $\mathrm{H}$ & $\mathrm{H}$ & $\mathrm{Cl}$ & $\mathrm{H}$ & 2.09012 & 21.65 & 1170 \\
\hline 47 & 4.408 & 4.836 & -0.428 & & $\mathrm{Br}$ & $\mathrm{H}$ & $\mathrm{COOH}$ & $\mathrm{H}$ & $\mathrm{H}$ & 2.08891 & 11.65 & 32 \\
\hline 48 & 6.301 & 5.836 & 0.465 & & $\mathrm{Br}$ & $\mathrm{H}$ & $\mathrm{H}$ & $\mathrm{Me}$ & $\mathrm{H}$ & 2.08883 & 31.65 & 32 \\
\hline 49 & 6.155 & 5.835 & 0.32 & & $\mathrm{Br}$ & $\mathrm{H}$ & $\mathrm{H}$ & $\mathrm{OMe}$ & $\mathrm{H}$ & 2.08988 & 81.65 & 32 \\
\hline 50 & 6.220 & 5.835 & 0.385 & & $\mathrm{Cl}$ & $\mathrm{H}$ & $\mathrm{H}$ & $\mathrm{Cl}$ & $\mathrm{H}$ & 2.08999 & 91.65 & 32 \\
\hline 51 & 7.032 & 6.974 & 0.058 & & $\mathrm{Br}$ & $\mathrm{H}$ & $\mathrm{H}$ & $\mathrm{CN}$ & $\mathrm{H}$ & 2.08913 & 31.7586 & 52 \\
\hline 52 & 6.398 & 6.017 & 0.381 & & $\mathrm{Br}$ & $\mathrm{H}$ & $\mathrm{H}$ & $\mathrm{Cl}$ & $\mathrm{H}$ & 2.08981 & 1.66239 & 79 \\
\hline $53^{*}$ & 5.377 & 12.192 & -6.815 & & $\mathrm{Cl}$ & $\mathrm{H}$ & $\mathrm{H}$ & $\mathrm{F}$ & $\mathrm{H}$ & 2.08995 & 2.25494 & 158 \\
\hline $54^{*}$ & 4.850 & 6.691 & -1.841 & & $\mathrm{Br}$ & $\mathrm{H}$ & $\mathrm{H}$ & $\mathrm{Cl}$ & $\mathrm{H}$ & 2.08962 & 1.72691 & 89 \\
\hline 55 & 6.222 & 5.809 & 0.413 & NN & $\mathrm{Br}$ & $\mathrm{H}$ & $\mathrm{H}$ & $\mathrm{Cl}$ & $\mathrm{H}$ & 2.0895 & 1.65 & 9 \\
\hline 56 & 6.319 & 5.835 & 0.484 & & $\mathrm{Br}$ & $\mathrm{H}$ & $\mathrm{H}$ & $\mathrm{CN}$ & $\mathrm{H}$ & 2.09108 & 31.65 & 32 \\
\hline
\end{tabular}


Tab. 2. (Cont.)

\begin{tabular}{|c|c|c|c|c|c|c|c|c|c|c|c|}
\hline \multicolumn{5}{|c|}{ No. Antagonist Activity } & \multicolumn{5}{|c|}{ Substitutions } & \multicolumn{2}{|c|}{ Structural Descriptors } \\
\hline & Act. pr & Pred. & i Resid. & & $\mathbf{R}^{2}$ & $\mathbf{R}^{3}$ & $\mathbf{R}^{4}$ & $\mathbf{R}^{5}$ & $\mathbf{R}^{6}$ & $\begin{array}{l}\text { Verloop Verloop } \\
\text { L B1 }\end{array}$ & $\begin{array}{l}\text { Weiner } \\
\text { Index }\end{array}$ \\
\hline 57 & 6.222 & 5.809 & 0.413 & $\mathrm{CH}_{2} \mathrm{NMe}_{2}$ & $\mathrm{Br}$ & $\mathrm{H}$ & $\mathrm{H}$ & $\mathrm{Cl}$ & $\mathrm{H}$ & 2.089491 .65 & 9 \\
\hline 58 & 4.996 & 5.945 & -0.949 & $\mathrm{CH}_{2} \mathrm{NMeBn}$ & $\mathrm{Br}$ & $\mathrm{H}$ & $\mathrm{H}$ & $\mathrm{Cl}$ & $\mathrm{H}$ & 2.088221 .65 & 126 \\
\hline 59 & 6.824 & 5.870 & 0.954 & & $\mathrm{Br}$ & $\mathrm{H}$ & $\mathrm{H}$ & $\mathrm{Cl}$ & $\mathrm{H}$ & 2.089491 .65 & 62 \\
\hline 60 & 6.456 & 5.846 & 0.61 & & $\mathrm{Br}$ & $\mathrm{H}$ & $\mathrm{H}$ & $\mathrm{Cl}$ & $\mathrm{H}$ & $2.0897 \quad 1.65$ & 41 \\
\hline 61 & 7.310 & 5.87 & 0.44 & & $\mathrm{Br}$ & $\mathrm{H}$ & $\mathrm{H}$ & $\mathrm{Cl}$ & $\mathrm{H}$ & 2.089581 .65 & 62 \\
\hline 62 & 6.824 & 5.869 & 0.955 & & $\mathrm{Br}$ & $\mathrm{H}$ & $\mathrm{H}$ & $\mathrm{Cl}$ & $\mathrm{H}$ & $2.0896 \quad 1.65$ & 61 \\
\hline 63 & 6.347 & 5.946 & 0.401 & & $\mathrm{Br}$ & $\mathrm{H}$ & $\mathrm{H}$ & $\mathrm{Cl}$ & $\mathrm{H}$ & 2.090041 .65 & 127 \\
\hline 64 & 6.553 & 5.870 & 0.683 & & $\mathrm{Br}$ & $\mathrm{H}$ & $\mathrm{H}$ & $\mathrm{Cl}$ & $\mathrm{H}$ & 2.089891 .65 & 62 \\
\hline 65 & 5.328 & 5.870 & -0.542 & & $\mathrm{Br}$ & $\mathrm{H}$ & $\mathrm{H}$ & $\mathrm{Cl}$ & $\mathrm{H}$ & 2.089571 .65 & 62 \\
\hline 66 & 5.509 & 5.946 & -0.437 & & $\mathrm{Br}$ & $\mathrm{H}$ & $\mathrm{H}$ & $\mathrm{Cl}$ & $\mathrm{H}$ & 2.089621 .65 & 127 \\
\hline 67 & 6.409 & 5.991 & 0.418 & & $\mathrm{Br}$ & $\mathrm{H}$ & $\mathrm{H}$ & $\mathrm{Cl}$ & $\mathrm{H}$ & 2.090191 .65 & 166 \\
\hline 68 & 6.398 & 6.050 & 0.348 & & $\mathrm{Br}$ & $\mathrm{H}$ & $\mathrm{H}$ & $\mathrm{Cl}$ & $\mathrm{H}$ & 2.089521 .65 & 216 \\
\hline 69 & 6.456 & 6.092 & 0.364 & & $\mathrm{Br}$ & $\mathrm{H}$ & $\mathrm{H}$ & $\mathrm{Cl}$ & $\mathrm{H}$ & 2.090151 .65 & 252 \\
\hline 70 & 5.071 & 5.938 & -0.867 & & $\mathrm{Br}$ & $\mathrm{H}$ & $\mathrm{H}$ & $\mathrm{Cl}$ & $\mathrm{H}$ & 2.089991 .65 & 120 \\
\hline
\end{tabular}

Tab. 3. Statistical significance of parameters in the TSAR derived model describing the antiHIV activity of phenoxybenzyl analogues

\begin{tabular}{|c|c|c|c|c|c|}
\hline Parameter & Coffifients $^{a}$ & Jackknife SE $^{b}$ & Covariance $\mathrm{SE}^{\mathrm{C}}$ & t-value $^{\mathrm{d}}$ & t-probability $^{\mathrm{e}}$ \\
\hline Verloop L (subs. 6) & -0.3828 & 0.0369 & 0.1215 & -3.1510 & 0.0031 \\
\hline Verloop B1 (subst.1) & 10.2653 & 2.6218 & 2.50722 & 4.0943 & 0.0002 \\
\hline $\begin{array}{l}\text { Weiner topological } \\
\text { index (subst.1) }\end{array}$ & 0.0012 & 0.0001 & 0.0001 & 11.4072 & $5.4068 \mathrm{e}-014$ \\
\hline Constant & -10.3396 & 4.34867 & & & \\
\hline
\end{tabular}


The QSAR model with a high statistical significance is represented by Equation 1:

Eq. 1. $Y=-0.3828491 X 1+10.265334 X 2+0.0011649015 X 3-10.339647$

Where $\mathrm{X} 1$ is verloop length parameter of substituent $6, \mathrm{X} 2$ is Verloop B1 of substituent 1 and $\mathrm{X} 3$ is Weiner topological index of substituent 1.

The statistics for this equation are shown in Table 1. As the model shows, the CCR5 blocking activity increases with an increase in the verloop B1 parameter and the weiner topological index of substituent 1 while the activity was found to decrease with an increase in the values for the verloop length parameter of substituent 6 . The verloop parameters [35-37] are a set of multi-dimensional steric descriptors that define a box that can be used to characterize the shape and volume of the substituent which are very important in explaining the steric influence of substituents in the interaction of organic compounds with macromolecular drug receptors. The verloop B1-B5 parameters describe the width of the substituent in the direction perpendicular to the length of the substituent. The study suggests that CCR5 antagonistic activity is strongly correlated with variations in the substituents at two positions of the general skeleton: namely, substitution on an ortho position of the phenoxy moiety and another ortho position to the benzyloxy group. The QSAR model shows that substitution on the ortho position of the phenoxy scaffold is strongly correlated with the antiretroviral activity as it is evident from the higher verloop B1 parameter coefficient (10.265) of substituents in the developed model. The verloop $L$ parameter, on the other hand, is found to negatively correlate with the antagonistic property. This apparently explains the difference in the activity of cpds 44 and 1 which differ only in their substitution on the ortho position of the benzyloxy moiety. Cpd 44 has got the higher activity for it showed a lower value for the negatively correlated length parameter at this position when compared to cpd 1 . The same reason appears to explain the lower activity of cpd 17 as compared to compounds 8, 9, 11-18, 20, 21, 47-50. These are cpompounds which has got the same values for the descriptor used in the QSAR except the length descriptor. Cpd 17 has got the highest (4.179) value for the negatively correlated descriptor which appears to reduce its CCR5 antagonist activity. That the verloop B1 steric parameter is positively related with the bioactivity is what is evident from biological activities of cpds 22, 23, 51. Cpd 51 has the higher activity as compared to 22 and $\mathbf{2 3}$ for it has a higher verlopp B1 parameter of the substituent that is positively correlated. Cpds with higher weiner's topological index for substituents at position 1 are showing a higher acticivity (see cpds 5-9) which is in harmony with the experimental know activity data. The QSAR suggests that of the six different points of substitution on the generic structure only variations on three points impact the activity greatly as shown in Figure 4. Considering the fact that the QSAR model was able to reproduce the experimental facts and that it was validated by the appropriate statistical procedures, it could be useful in designing more potent antagonists. 


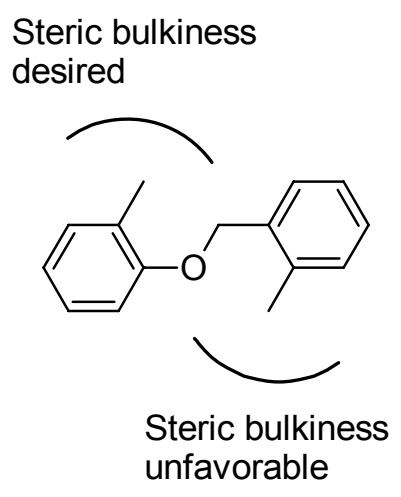

Fig. 4. Representation of regions where steric bulkiness is desired and undesired.

\section{Conclusions}

HIV co receptors have emerged as important drug targets with huge therapeutic potentials for their antagonists. The QSAR analysis using 70 phenoxybenzyl derivatives was successfully carried out to build a statistically significant model possessing a good correlative and predictive capability for the inhibition of CCR5 co receptor. The 2D-QSAR model was validated by standard statistical means and through observation on how it reproduces and explains the quantitative differences seen in the experimentally known activity data. The detailed structural investigation revealed that the antidepressant activity is predominantly explained by the steric factors of the substituent which govern the CCR5 antagonist-CCR5 interaction chemistry. The comparative investigation provided structural insights on how modulation of the steric bulk of the substituents could be usefully made to optimize the antiretroviral activity. The study provided useful clues about the structural requirement for effective antagonist-CCR5 interaction chemistry and hence for the improvement of the observed biological activity. This analysis could be of help in the rational design of potential drug candidates with an enhanced antagonistic potency.

\section{Author's Statement}

\section{Competing Interests}

The author declares no conflict of interest.

\section{References}

[1] Palella FJ, Delaney KM, Moorman AC, Loveless MO, Fuhrer J, Satten GA, Aschman DJ, Holmberg SD.

Declining Morbidity and Mortality among Patients with Advanced Human Immunodeficiency Virus Infection.

N Engl J Med. 1998; 338: 853-860.

PMid:9516219

[2] Finzi D, Blankson J, Siliciano JD, Margolick JB, Chadwick K, Pierson T, Smith K, Lisziewicz J, Lori F, Flexner C, Quinn TC, Chaisson RE, Rosenberg E, Walker B, Gange S, Gallant J, Siliciano RF. Latent infection of CD4 T cells provides a mechanism for lifelong persistence of HIV-1. Nat Med. 1999; 5: 512-517. doi:10.1038/8394 
[3] Chun T,W., Davey RT, Engel D., Lane HC, Fauci AS.

Re-emergence of HIV alter stop- ping therapy.

Nature. 1999; 401: 874-875.

doi: $10.1038 / 44755$

[4] Deeks SG, Smith M, Holodniy M, Kahn JO.

HIV-1 protease inhibitors. A review for clinicians.

JAMA. 1997; 277: 145-153.

doi:10.1001/jama.277.2.145

[5] Martinez-Picado J, DePasquale MP, Kartsonis N, Hanna GJ, Wong J, Finzi D, Rosenberg E, Günthard HF, Sutton L, Savara A, Petropoulos CJ, Hellmann N, Walker BD, Richman D, Siliciano R, D'Aquila RT.

Antiretroviral Resistance during Successful Therapy of HIV Type 1 Infection.

Proc Natl Acad Sci U S A. 2000; 97: 10948-10953.

doi:10.1073/pnas.97.20.10948

[6] Blair WS, Lin PF, Meanwell NA, Wallace OB.

HIV-1 entry--an expanding portal for drug discovery.

Drug Discov Today. 2000; 5: 183-194.

doi:10.1016/S1359-6446(00)01484-7

[7] Kilby JM, Hopkins S, Venetta TM, DiMassimo B, Cloud GA, Lee JY, Alldredge L, Hunter E, Lambert D, Bolognesi D, Matthews T, Johnson MR, Nowak M A, Shaw GM, Saag MS.

Potent suppression of HIV-1 replication in humans by T-20, a peptide inhibitor of gp41-mediated CCR5 binding.

Nat Med. 1998; 4: 1302-1307.

doi:10.1038/3293

[8] Connor RI, Sheridan KE, Ceradini D, Choe S, Landau NR.

Change in Coreceptor Use Correlates with Disease Progression in HIV-1-Infected Individuals.

J Exp Med. 1997; 185: 621-628.

doi:10.1084/jem.185.4.621

[9] Saunders J, Tarby CM.

Opportunities for novel therapeutic agents acting at chemokine receptors.

Drug Discov Today. 1999; 4: 80-92.

doi:10.1016/S1359-6446(98)01280-X

[10] Cocchi F, DeVico AL, Garzino-Demo A, Arya SK, Gallo RC, Lusso P.

Identification of RANTES, MIP-1, and MIP-1 as the Major HIV-Suppressive Factors Produced by CD8+ T Cells.

Science. 1995; 270: 1811-1815.

doi:10.1126/science.270.5243.1811

[11] Dean M, Carrington M, Winkler C, Huttley GA, Smith MW, Allikmets R, Goedert JJ, Buchbinder SP, Vittinghoff E, Gomperts E, Donfield S, Vlahov D, Kaslow R, Saah A, Rinaldo C, Detels R, O'Brien SJ. Genetic Restriction of HIV-1 Infection and Progression to AIDS by a Deletion Allele of the CKR5 Structural Gene.

Science. 1996; 273: 1856-1862.

doi:10.1126/science.273.5283.1856

[12] Liu R, Paxton WA, Choe S, Ceradini D, Martin SR, Horuk R, MacDonald M E, Stuhlmann H, Koup RA, Landau NR.

Homozygous Defect in HIV-1 Coreceptor Accounts for Resistance of Some Multiply Exposed

individuals to HIV-1 Infection

Cell. 1996; 86: 367-377.

doi:10.1016/S0092-8674(00)80110-5 
[13] Samson M, Libert F, Doranz BJ, Rucker J, Liesnard C, Farber CM, Saragosti S, Lapouméroulie C, Cognaux J, Forceille C, Muyldermans G, Verhofstede C, Burtonboy G, Georges M, Imai T, Rana S, Smyth RJ, Collman RG, Doms RW, Vassart G, Parmentier M.

Resistance to HIV-1 infection in Caucasian individuals bearing mutant alleles of the CCR-5 chemokine receptor gene.

Nature. 1996; 382: 722-725.

doi:10.1038/382722a0

[14] Michael NL, Chang G, Louie LG, Mascola JR, Dondero D, Birx DL, Sheppard HW.

The role of viral phenotype and CCR-5 gene defects in HIV-1 transmission and disease progression.

Nat Med. 1997; 3: 338-340.

doi:10.1038/nm0397-338

[15] Finke PE, Oates B, Mills SG, MacCoss M, Malkowitz L, Springer MS, Gould SL, DeMartino JA, Carella A, Carver G, Holmes K, Danzeisen R, Hazuda D, Kessler J, Lineberger J, Miller M, Schleif WA, Emini EA.

Antagonists of the human CCR5 receptor as anti-HIV-1 agents. Part 2: structure-activity relationships for substituted 2-aryl-1-[N-(methyl)- $N$-(phenylsulfonyl) amino]-4-(piperidin-1-yl) butanes.

Bioorg Med Chem Lett. 2001; 11: 2475-2479.

doi:10.1016/S0960-894X(01)00492-9

[16] Lynch CL, Hale JJ, Budhu RJ, Gentry AL, Mills SG, Chapman KT, MacCoss M, Malkowitz L, Springer MS, Gould SL, DeMartino JA, Siciliano SJ, Cascieri M A, Carella A, Carver G, Holmes K, Schleif WA, Danzeisen R, Hazuda D, Kessler J, Lineberger J, Miller M, Emini EA.

1,3,4-Trisubstituted pyrrolidine CCR5 receptor antagonists. Part 4: Synthesis of N-1 acidic functionality affording analogues with enhanced antiviral activity against HIV.

Bioorg Med Chem Lett. 2002; 12: 3001-3004.

doi:10.1016/S0960-894X(02)00606-6

[17] Palani A, Shapiro S, Clader JW, Greenlee WJ, Cox K, Strizki J, Endres M, Baroudy BM.

Discovery of 4-[(Z)-(4-Bromophenyl)- (ethoxyimino)methyl]-1'- (2,4-dimethyl-3-pyridinyl)carbonyl]-4'methyl-1,4'-bipiperidine N-Oxide (SCH 351125): An Orally Bioavailable Human CCR5 Antagonist for the Treatment of HIV Infection.

J Med Chem. 2001; 44: 3339-3342.

doi:10.1021/jm015526o

[18] Tagat JR, Steensma RW, McCombie SW, Nazareno DV, Lin S, Neustadt BR, Cox K, Xu S, Wojcik L,. Murray MG, Vantuno N, Baroudy BM, Strizki J M.

Piperazine-Based CCR5 Antagonists as HIV-1 Inhibitors.II. Discovery of 1-[(2,4-Dimethyl-3pyridinyl)carbonyl]-4-methyl-4-[3(S)-methyl-4-[1(S)-[4- trifluoromethyl) phenyl]ethyl]-1-piperazinyl]piperidine N1-Oxide (Sch-350634), an Orally Bioavailable, Potent CCR5Antagonist.

J Med Chem. 2001; 44: 3343-3346.

doi:10.1021/jm0155401

[19] Maeda K, Yoshimura K, Shibayama S, Habashita H, Tada H, Sagawa K, Miyakawa T, Aoki M, Fukushima D, Mitsuya H.

Novel Low Molecular Weight Spirodiketopiperazine Derivatives Potently Inhibit R5 HIV-1 Infection through Their Antagonistic Effects on CCR5.

J Biol Chem. 2001; 276: 35194-35200.

doi:10.1074/jbc.M105670200

[20] Sagawa K, Miyakawa T, Aoki M, Fukushima D, Mitsuya H.

Novel Low Molecular Weight Spirodiketopiperazine Derivatives Potently Inhibit R5 HIV-1 Infection through Their Antagonistic Effects on CCR5.

J Biol Chem. 2001; 276: 35194-35200.

doi:10.1074/jbc.M105670200

[21] Armour DR, Price DA, Stammen BLC, Wood A, Perros M, Edwards MP. PCT Int. Appl. WO 00/39125 (2000).

[22] Bondinell WE, Ku, TW, Wang N.

PCT Int. Appl. WO 00/40239 (2000). 
[23] Klocker J, Wailzer B, Buchbauer G, Wolschann P.

Bayesian neural networks for aroma classification.

J Chem Inf Comput Sci. 2002; 42: 1443-1449.

doi:10.1021/ci0202640

[24] Kovatcheva A, Buchbauer G, Golbraikh A, Wolschann P.

QSAR Modeling of alpha-Campholenic Derivatives with Sandalwood Odor.

J Chem Inf Comput Sci. 2003; 43: 259-266.

doi:10.1021/ci020296n

[25] Kubinyi $\mathrm{H}$.

QSAR and 3D-QSAR in Drug Design. Part 1: Methodology.

Drug Discovery Today. 1997; 2: 457-467.

doi:10.1016/S1359-6446(97)01079-9

[26] Dessalew N, Bharatam PV.

3D-QSAR and molecular docking study on bisarylmaleimide series as glycogen synthase kinase 3 , cyclin dependent kinase 2 and cyclin dependent kinase 4 inhibitors: An insight into the criteria for selectivity.

Eur J Med Chem. 2007; 42: 1014-1027.

doi:10.1016/j.ejmech.2007.01.010

[27] Dessalew N, Patel DS, Bharatam PV.

3D-QSAR and molecular docking studies on pyrazolopyrimidine derivatives as glycogen synthase kinase-3b inhibitors.

J Mol Graph Mod. 2007; 25: 885-895.

doi:10.1016/j.jmgm.2006.08.009

[28] Dessalew N, Bharatam PV, Singh SK.

3D-QSAR CoMFA Study on Aminothiazole Derivatives as Cyclin-Dependent Kinase 2 Inhibitors.

QSAR Comb Sci. 2007; 26: 85-91.

doi:10.1002/qsar.200630032

[29] Dessalew N.

QSAR study on aminophenylbenzamides and acrylamides as histone deacetylase inhibitors: An insight into the structural basis of antiproliferative activity.

Med. Chem. Res. 2008; 16: 449-460.

doi:10.1007/s00044-007-9085-9

[30] Dessalew N.

QSAR study on 5-HT1A and 5-HT1B antagonists: An insight into structural requirement for antidepressant activity.

Arch Pharm., 2008; 341: 314-322.

doi:10.1002/ardp.200700224

[31] Lohray BB, Gandhi N, Srivastava KB, Lohray VB.

3D-QSAR studies of N-4-arylacryloylpiperazin-1-yl-phenyloxazolidinone s: A novel class of antibacterial agents.

Bioorg Med Chem Lett. 2006; 16: 3817-3823.

doi:10.1016/j.bmcl.2006.04.023

[32] Tronchet JMJ, Grigorov M, Dolatshahi N, Moriaud F, Weber J.

A QSAR study confirming the heterogeneity of the HEPT derivative series regarding their interaction with HIV reverse transcriptase.

Eur J Med Chem. 1997; 32: 279-299.

doi:10.1016/S0223-5234(97)89081-2

[33] Robert GW, Arnaiz DO, Chou YL, Davey D, Dunning L, Lee W, Lu SF, Onuffer J, Ye B, Phillips G. CCR5 receptor antagonists: Discovery and SAR study of guanylhydrazone derivatives.

Bioorg Med Chem Lett. 2007; 17: 231-234.

doi:10.1016/j.bmcl.2006.09.052 
[34] Lu SF, Chen B, Davey D, Dunning L, Jaroch S, May K, Onuffer J, Phillips G, Subramanyam B, Tseng JL,. Wei RG, Wei M, Ye B.

CCR5 receptor antagonists: Discovery and SAR of novel 4- hydroxypiperidine derivatives.

Bioorg Med Chem Lett. 2007; 17: 1883-1887.

doi:10.1016/j.bmcl.2007.01.050

[35] Verloop A, Hoogenstraaten W, Tipker J.

Development and application of new steric substituent parameters in drug design.

In Drug design (ed. E. J. Ariens).

New York, Academic Press. 1976; 7: 165-207.

[36] Verloop A, Tipker J.

Use of linear free energy related and other parameters in the study of fungicidal selectivity. Pestic Sci. 1976; 7: 379-390.

doi:10.1002/ps.2780070410

[37] Verloop A, Tipker J.

A comparative study of new parameters in drug design.

In Biological activity and chemical structure (ed. J. A. Keverling Buisman).

Amsterdam: Elsevier. 1977, 63-81. 